\title{
Effectiveness of treatment with pegylated interferon and ribavirin in an unselected population of patients with chronic hepatitis C: A Danish nationwide cohort study
}

Nanna Hansen ${ }^{1}$, Niels Obel ${ }^{2}$, Peer B Christensen ${ }^{3}$, Mette Kjær ${ }^{4}$, Alex L Laursen ${ }^{5}$, Henrik B Krarup ${ }^{6}$, Axel Møller ${ }^{7}$, Poul Schlichting ${ }^{8}$, Jens Bukh ${ }^{9}$, Nina Weis ${ }^{1,10^{*}}$ and for the Danish Database for Hepatitis B and C (DANHEP)- group

\begin{abstract}
Background: The effect of peginterferon and ribavirin treatment on chronic hepatitis $\mathrm{C}$ virus (HCV) infection has been established in several controlled clinical studies. However, the effectiveness of treatment and predictors of treatment success in routine clinical practice remains to be established. Our aim was to estimate the effectiveness of peginterferon and ribavirin treatment in unselected HCV patients handled in routine clinical practice. The endpoint was sustained virological response (SVR), determined by the absence of HCV RNA 24 weeks after the end of treatment.

Methods: We determined the proportion of SVR in a nationwide, population-based cohort of 432 patients with chronic HCV infection who were starting treatment, and analyzed the impact of known covariates on SVR by using a logistic regression analysis.

Results: The majority of treated patients had genotype 1 (133 patients) and genotype 2/3 (285 patients) infections, with $44 \%$ and $72 \%$, respectively, obtaining SVR. Other than genotype, the predictors of SVR were age $\leq 45$ years at the start of treatment, completion of unmodified treatment, the absence of cirrhosis and non-European origin.

Conclusions: The effectiveness of peginterferon and ribavirin treatment for chronic hepatitis $C$ in a routine clinical practice is comparable to that observed in controlled clinical trials, with a higher SVR rate in genotype 2 and 3 patients compared to genotype 1 patients. Our data further indicate that age at start of treatment is a strong predictor of SVR irrespective of HCV genotype, with patients 45 years or younger having a higher SVR rate.
\end{abstract}

\section{Background}

Combination therapy with peginterferon and ribavirin has improved treatment response in patients with chronic hepatitis $\mathrm{C}$ virus (HCV) infection, but the virus is still only eradicated in $50-80 \%$ of the patients receiving treatment [1-3], depending on $\mathrm{HCV}$ genotype. Treatment is lengthy and has severe side effects, which may lead to dose reduction or even prevent treatment completion. There are also several contraindications to starting treatment, such as ongoing psychiatric disease

\footnotetext{
*Correspondence: ninaweis@dadlnet.dk

'Department of Infectious Diseases, Copenhagen University Hospital, Hvidovre, 2650 Hvidovre, Denmark

Full list of author information is available at the end of the article
}

or active intravenous drug use (IDU). Progress has been made in the development of new direct-acting antiviral drugs, specifically targeting viral replication, and some of these antivirals have recently been studied in clinical trials. The results are promising especially for certain protease inhibitors expected to be licensed soon for the treatment of chronic HCV infection, as part of triple therapy with peginterferon and ribavirin [4]. It is, however, still uncertain when these new agents will be introduced into routine clinical practice.

Most previous studies of antiviral treatment response in HCV infected patients have included specific and often highly selected groups of patients (patients in clinical trials, in tertiary hospitals etc.), and these studies

\section{Biomed Central}


are therefore prone to be affected by selection bias. It was found that female gender, young age, being infected with genotype 2 or 3 , absence of cirrhosis, Asian origin and early inhibition of viral replication predict a better response to treatment [5-17]. It is however, controversial whether the promising treatment effects observed in clinical trials can be transformed into an equivalent effectiveness in a routine clinical setting, although one retrospective observational cohort study by Backus et al. of patients treated in a routine clinical setting at Veterans Affairs facilities showed efficacy of treatment to be 20-52\% [12].

The aim of the present study was to estimate the effectiveness of treatment for chronic HCV infection with peginterferon and ribavirin in a nationwide, population based cohort of $\mathrm{HCV}$ infected patients.

\section{Methods \\ Setting}

The prevalence of chronic HCV infection in Denmark was estimated by the Danish National Board of Health to be around $0.3 \%$ (15,000 individuals) [18]. Approximately $25 \%$ of these individuals are, or have been, monitored in specialized hospital departments, where antiviral therapy for $\mathrm{HCV}$ infection is provided for all patients found to be in need of treatment.

\section{The Danish Database for Hepatitis B and C (DANHEP)}

DANHEP was established in January 2002 as a nationwide open cohort study with ongoing enrolment. It includes data about individuals in Denmark who are chronically infected with hepatitis B and/or C, are 16 years of age or older, are followed in one of the 11 medical departments that monitor and treat patients with chronic hepatitis in Denmark, and have been seen at least once after 1 January 2002 in one of these departments. The database is described in detail elsewhere [19].

\section{Tests for HCV RNA and HCV genotype}

For 9 of the 11 departments recruiting patients to the DANHEP study, serum HCV-RNA was quantified in one laboratory by a previously described RT-PCR method with a detection limit of $20 \mathrm{IU} / \mathrm{mL}$ [20]. Here, $\mathrm{HCV}$-genotype was determined in RT-PCR with genotype specific primers from the 5 ' non-coding region of the virus genome [21]. The remaining two departments in DANHEP used either COBAS AmpliPrep/COBAS TaqMan HCV test (Roche diagnostics, Branchburg, NJ) (detection limit $15 \mathrm{IU} / \mathrm{mL}$ ), COBAS Amplicor $\mathrm{HCV}$ Monitor (Roche diagnostics) (detection limit $300 \mathrm{IU} /$ $\mathrm{mL}$ ) or qualitative HCV-RNA measurements (detection limit $50 \mathrm{IU} / \mathrm{mL}$ ) to quantify HCV-RNA and the Versant HCV Genotyping Assay, LiPA (Bayer HealthCare LCC) to determine the HCV genotype. Here, genotype was also, in some cases analyzed using conserved primers deduced from the core-envelope 1-region of the virus in RT-PCR followed by sequence analysis [22]. All samples tested for the presence of HCV RNA 24 weeks after the end of treatment were tested using one of the methods with detection limit of $50 \mathrm{IU} / \mathrm{mL}$ or lower.

Although HCV genotype 6 is not found in Danish patients [22], it is widely present in Asia. We therefore re-analyzed Asian patients found to be infected with genotype 1 , if the genotype was determined in RT-PCR with primers from the HCV 5' non-coding region, because this is not a valid method to distinguish genotype 1 from 6. The re-analysis was performed in RT-PCR of the Core-E1 region and the NS5B-region followed by sequence analysis of the resulting amplicons [22,23].

\section{Study population}

All treatment naive patients, registered in DANHEP with chronic HCV infection, who started combination therapy with peginterferon and ribavirin between 1 January 2002 and 1 January 2007, were included in the study (table 1). Patients were included regardless of whether they had completed treatment or not, even if they had only received one dosage of peginterferon. Patients with positive HBsAg or positive anti-HIV antibody test were excluded. In addition, 63 patients were excluded because HCV-RNA status test at treatment initiation was not available.

Treatment with either pegylated interferon alpha-2a (Pegasys ${ }^{\circledR}$, Roche A/S, Basel, Switzerland) or alpha-2b (PegIntron ${ }^{\circledR}$, Schering-Plough, Kenilworth, NJ, USA) was given weekly according to the manufacturer's instructions. Ribavirin (Copegus ${ }^{\circledR}$, Roche or Rebetol ${ }^{\circledR}$, ScheringPlough) was given daily, adjusted to body weight for genotypes 1 and 4 or as "flat dosage" for genotypes 2 and 3 , according to the manufacturer's instructions. The duration of therapy was planned for 48 weeks for genotype 1 and 4 and 24 weeks for genotype 2 and 3 . Some patients with genotype 2 or 3 who were included in a clinical trial were randomized to 12 weeks of treatment [9]. Other genotype 2 or 3 infected patients participating in another clinical trial were randomized to 14 or 24 weeks of treatment, if they had a negative HCV-RNA after 4 weeks [8]. In general, if HCV-RNA titers had not decreased by a minimum of 2 logs after 12 weeks of treatment, treatment was stopped according to international guidelines.

\section{Study outcome}

Treatment outcome was evaluated 24 weeks after end of treatment, where patients with undetectable HCVRNA were categorized as responders, having achieved sustained virological response (SVR). Patients with 
Table 1 Baseline characteristics of $\mathbf{4 3 2}$ patients chronically infected with HCV, treated with peginterferon and ribavirin in Denmark between 1 January 2002 and 1 January 2007

\begin{tabular}{|c|c|c|c|}
\hline & & \multicolumn{2}{|c|}{ Whole cohort } \\
\hline & & $S V R$ & Non-SVR \\
\hline Total & & 274 & 158 \\
\hline Gender & Male & $177(64.5)$ & $105(66.5)$ \\
\hline \multirow[t]{2}{*}{ Nationality } & European & $226(82.5)$ & $146(92.4)$ \\
\hline & Non-European & $48(17.5)$ & $12(7.6)$ \\
\hline \multirow[t]{3}{*}{ Route of infection } & IDU & $145(52.9)$ & $74(46.8)$ \\
\hline & non-IDU & $37(13.5)$ & $30(19.0)$ \\
\hline & Unknown & $92(33.6)$ & $54(34.2)$ \\
\hline $\begin{array}{l}\text { Age at treatment } \\
\text { initiation }\end{array}$ & $\leq 45$ years & $148(54.0)$ & $49(31.0)$ \\
\hline \multirow[t]{6}{*}{ Genotype } & 1 & $59(21.5)$ & $74(46.8)$ \\
\hline & 2 & $37(13.5)$ & $13(8.2)$ \\
\hline & 3 & $168(61.3)$ & $67(42.4)$ \\
\hline & 4 & $6(2.2)$ & $4(2.5)$ \\
\hline & 6 & $2(0.7)$ & 0 \\
\hline & Unknown & $2(0.7)$ & 0 \\
\hline HCV-RNA & $>600.000 \mathrm{IU} / \mathrm{mL}$ & $92(33.6)$ & $77(48.7)$ \\
\hline Elevated ALT & $2 \times \mathrm{UNL}^{*}$ & $149(54.4)$ & $73(46.2)$ \\
\hline \multirow{2}{*}{$\begin{array}{l}\begin{array}{l}\text { Treating } \\
\text { Department } \\
\text { (speciality) }\end{array} \\
\end{array}$} & Infectious Diseases & $177(64.6)$ & $101(63.9)$ \\
\hline & $\begin{array}{l}\text { Gastroenterology/ } \\
\text { Hepatology }\end{array}$ & $97(35.4)$ & $57(36.1)$ \\
\hline $\begin{array}{l}\text { Liver biopsy within } \\
3 \text { years }\end{array}$ & Yes & $152(55.5)$ & $98(62.0)$ \\
\hline \multirow{4}{*}{$\begin{array}{l}\text { Treatment } \\
\text { completion }\end{array}$} & As planned & $193(70.4)$ & $65(41.1)$ \\
\hline & With dose reduction & $55(20.1)$ & $43(27.2)$ \\
\hline & $\begin{array}{l}\text { Ended before } \\
\text { scheduled }\end{array}$ & $24(8.8)$ & $39(24.7)$ \\
\hline & Unknown & $2(0.7)$ & $11(7.0)$ \\
\hline
\end{tabular}

Data according to those achieving sustained virological response (SVR) versus non-SVR.

Numbers in parenthesis is \% of persons with SVR and non-SVR respectively. UNL, upper normal limit

${ }^{*} 2 \times \mathrm{UNL}=\mathrm{ALT}>70 \mathrm{IU} / \mathrm{L}$ (female), ALT > $100 \mathrm{IU} / \mathrm{L}$ (male)

IDU, Intravenous drug use

detectable HCV-RNA levels 24 weeks after end of treatment were categorized as non-responders.

\section{Statistics}

Logistic regression analyses were used to evaluate potential predictors of SVR, estimating odds ratios (OR) and 95\% confidence intervals (CI). We calculated unadjusted and adjusted OR with the following covariates included in the model: Gender, nationality (European vs. NonEuropean, route of infection (Intravenous drug use (IDU) vs. non-IDU), age at treatment initiation $(\leq 45$ years vs. > 45 years), HCV genotype (genotype 1 vs. type 2 and 3$)$, ALT at treatment initiation $(\leq 2 \times \mathrm{UNL}$ vs. $>2 \times \mathrm{UNL}), \mathrm{HCV}-\mathrm{RNA}$ at treatment initiation ( $\leq$ $600.000 \mathrm{IU} / \mathrm{mL}$ vs. $>600.000 \mathrm{IU} / \mathrm{mL})$, and type of hospital department (Infectious Diseases vs. Gastroenterology/Hepatology). We also adjusted for treatment completion (as scheduled vs. with dose reduction vs. ended before scheduled) (table 2). For those who had a liver biopsy performed within 3 years prior to treatment initiation, we made sub analyses adding the result of the biopsy to the model; cirrhosis vs. not cirrhosis (METAVIR score [24]).

Previous studies have shown that patients infected with genotype $2 / 3$ have a higher response rate to combination therapy, and we therefore performed the analysis stratified on HCV genotype (genotype 1 vs. genotype 2/3). Because only 10 and 2 patients were infected with $\mathrm{HCV}$ genotype 4 and 6 , respectively, these patients were not included in the analyses stratified on HCV genotype.

Starting treatment at a younger age has been associated with higher SVR rates $[1,6,8,9,25]$. Some studies have included age as a dichotomized variable, while others have included age in the models as a continuous variable. We divided the cohort according to age in 10 groups of equal size and made logistic regression analyses to estimate beta values, to evaluate whether to use a continuous age scale or a specific cut-off point and if so, to estimate the best cut-off point. We observed a sharp drop in beta values between the ages of 43-47, and therefore age was modeled in the regression analysis as equal to or less than 45 vs. over 45 years of age at start of treatment.

Data analyses were performed using SPSS statistical analysis version 16.0 (SPSS, Chicago, Illinois, USA). The Study was approved by the Danish Data Protection Agency (J. nr. 2007-41-0815).

\section{Results}

\section{Study population characteristics}

In total, 432 chronically infected $\mathrm{HCV}$ patients were included in the study (table 1). Among the 372 patients of European origin, 327 (87.9\%) were Danish. The group of non-Europeans consisted of 10 African-, 3 American-, 9 Asian-, 15 Pakistani-, and 15 Middle Eastern patients. Eight patients had an unknown country of origin. Median age at treatment initiation was 46 years, (range 20-71). Twenty-eight patients (6.5\%) received lower start doses of peginterferon, ribavirin, or both, than recommended by the manufacturer.

Genotyping revealed that $133(30.8 \%)$ patients were infected with genotype 1, 50 (11.6\%) with genotype 2, 235 (54.4\%) with genotype 3, 10 (2.3\%) with genotype 4, and 2 patients with genotype $6(0.5 \%)$. In 2 patients (0.5\%) the HCV genotype was unknown. 
Table 2 Unadjusted and adjusted odds ratios and $95 \%$ confidence intervals (CI) for sustained virological response after treatment with peginterferon and ribavirin in $\mathbf{4 3 2}$ chronically HCV infected patients, according to predictor variables

\begin{tabular}{|c|c|c|c|}
\hline & Predictor variable & $\begin{array}{c}\text { Odds ratio }(95 \% \mathrm{Cl}) \\
\text { unadjusted }\end{array}$ & $\begin{array}{c}\text { Odds ratio }(95 \% \mathrm{Cl}) \\
\text { adjusted }\end{array}$ \\
\hline \multirow[t]{2}{*}{ Gender } & Female & 1 & 1 \\
\hline & Male & $0.92(0.61-1.39)$ & $0.80(0.50-1.27)$ \\
\hline \multirow[t]{2}{*}{ Nationality } & European & 1 & 1 \\
\hline & Non-European & $2.53(1.23-5.21)$ & $3.03(1.20-7.67)$ \\
\hline \multirow[t]{3}{*}{ Route of infection } & Non-IDU & 1 & 1 \\
\hline & IDU & $1.59(0.91-2.77)$ & $1.43(0.76-2.69)$ \\
\hline & Unknown & $1.38(0.77-2.49)$ & $1.21(0.61-2.41)$ \\
\hline \multirow[t]{2}{*}{ Age } & Age $\leq 45$ years at treatment initiation & 1 & 1 \\
\hline & Age $>45$ years at treatment initiation & $0.38(0.25-0.58)$ & $0.47(0.30-0.74)$ \\
\hline \multirow[t]{2}{*}{ Genotype } & 1 & 1 & 1 \\
\hline & 2 or 3 & $3.01(1.97-4.60)$ & $2.31(1.45-3.69)$ \\
\hline \multirow[t]{2}{*}{ HCV-RNA } & $\leq 600.000 \mathrm{IU} / \mathrm{mL}$ & 1 & 1 \\
\hline & $>600.000 \mathrm{IU} / \mathrm{mL}$ & $0.53(0.36-0.79)$ & $0.70(0.45-1.10)$ \\
\hline \multirow[t]{2}{*}{$A L T$} & Less than $2 \times \mathrm{UNL}^{*}$ & 1 & 1 \\
\hline & More than $2 \times$ UNL & $1.39(0.94-2.06)$ & $1.40(0.91-2.16)$ \\
\hline \multirow[t]{2}{*}{ Treating department (speciality) } & Gastroenterology/Hepatology & 1 & 1 \\
\hline & Infectious Diseases & $1.03(0.69-1.55))$ & $0.93(0.59-1.49)$ \\
\hline \multirow[t]{2}{*}{ Liver biopsy } & Not cirrhosis & 1 & \\
\hline & Cirrhosis & $0.44(0.25-0.79)^{\S}$ & \\
\hline \multirow[t]{3}{*}{ Treatment completion } & As shceduled & 1 & 1 \\
\hline & With dose reduction & $0.55(0.34-0.90)$ & $0.57(0.33-0.96)$ \\
\hline & Ended before scheduled & $0.22(0.12-0.38)$ & $0.26(0.14-0.47)$ \\
\hline
\end{tabular}

UNL, upper normal limit

* $2 \times \mathrm{UNL}=\mathrm{ALT}>70 \mathrm{IU} / \mathrm{L}$ (female), ALT > $100 \mathrm{IU} / \mathrm{L}$ (male)

${ }^{\S}$ Only 250 of the 432 patients had a liver biopsy done. Thisparameter is therefore not included in the adjusted analyses.

IDU, Intravenous drug use

Effectiveness of treatment with pegylated interferon and ribavirin and predictors of SVR

The overall SVR rate was $63 \%$, with rates of $44 \%, 74 \%$, $71 \%$ and $60 \%$ for patients with genotypes 1, 2, 3 and 4 , respectively (table 1 ). Both patients with genotype 6 infection obtained SVR.

Genotype, age and nationality all had substantial impact on the fraction of patients who obtained SVR (table 2). Patients infected with genotype $2 / 3$ had an OR of 2.3 for SVR compared to genotype 1 and patients who initiated treatment at age of $\leq 45$ years had an OR of 2.1 for SVR. The impact of age at treatment initiation was seen for genotype 1 as well as $2 / 3$, although it was not statistically significant for the latter group (table 3 ). Figure 1 shows SVR rates according to age. When analyzing only the group of patients $\leq 45$ years, genotype was still a predictor of SVR, though not statistically significant, while it was a significant predictor of SVR in the group $>45$ years at treatment initiation (table 4 ).
Also the group of non-Europeans had a significantly higher SVR rate with an OR of 3.03 for SVR.

In an analysis only including patients who had had a liver biopsy performed prior to treatment initiation, we found that cirrhosis was negatively associated with SVR,

Table 3 Odds ratios and 95\% confidence intervals (CI) for age as predictor of sustained virological response after treatment with peginterferon and ribavirin in $\mathbf{4 1 8}$ chronically HCV infected patients, divided by genotype (133 genotype 1, 285 genotype 2/3)

\begin{tabular}{lccc}
\hline & Genotype 1 & Genotype $2 / 3$ \\
\hline & & Odds ratio $(\mathbf{9 5} \% \mathrm{Cl})^{*}$ & Odds ratio $(\mathbf{9 5 \%} \mathrm{Cl})^{*}$ \\
\hline Age & $\leq \mathbf{4 5}$ years & 1 & 1 \\
\hline & $>$ 45 years & $0.23(0.09-0.63)$ & $0.58(0.33-1.00)$ \\
\hline
\end{tabular}

*adjusted for gender, nationality, route of infection, HCV-RNA, ALT, treating department (gastroenterology/hepatology vs. infectious diseases), treatment completion as scheduled, ended before scheduled or dose reduction 


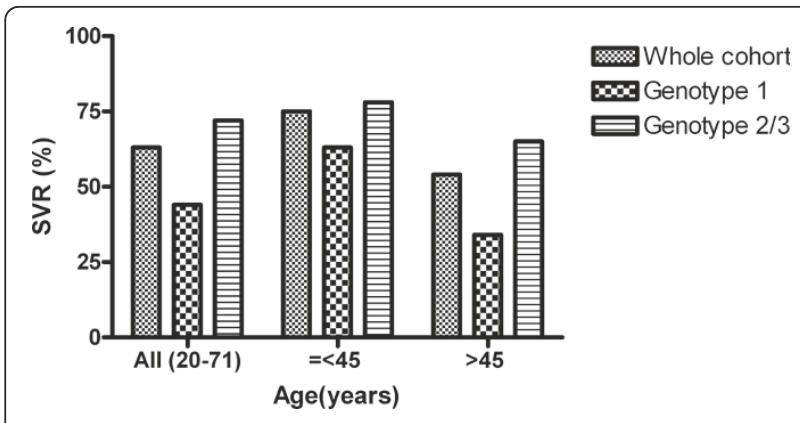

Figure 1 Sustained virological response (SVR) as a function of age, at antiviral treatment initiation in patients with chronic hepatitis $\mathbf{C}$. The figure illustrates SVR in the total cohort and SVR depending on genotype, in different age groups. In all, 274 of 432 achieved SVR. 197 patients were $\leq 45$ years (148 achieved SVR) and 235 patients were $>45$ years (126 achieved SVR). Of the 133 patients with genotype 1 infection, 47 were $\leq 45$ years (30 achieved SVR), and of the 285 genotype 2/3 infected patients, 144 were $\leq 45$ years (113 achieved SVR)

but the effect became statistically insignificant after adjustment of other co-factors (table 2).

Data available after treatment initiation showed that dose reduction or stopping treatment before scheduled were strongly associated with a reduced chance of SVR (table 2).

\section{Discussion}

In a nationwide population based cohort of chronically infected $\mathrm{HCV}$ patients we observed sustained virological response (SVR) rates of $44 \%$ and $72 \%$ for genotype 1 and $2 / 3$ respectively, after combination therapy with peginterferon and ribavirin. Other main predictors of SVR were age $\leq 45$ years at treatment initiation and completion of non-modified treatment regimens. Finally, being of Non-European nationality predicted a higher SVR rate.

While several controlled clinical trials have evaluated effectiveness of treatment with peginterferon and ribavirin in $\mathrm{HCV}$ infected patients, the effectiveness of treatment in a routine clinical setting is less well shown $[10,25]$, except for one retrospective, observational cohort study by Backus et al. with SVR rates of $20 \%$,

Table 4 Odds ratios and $95 \%$ confidence intervals $(\mathrm{Cl})$ for genotype as predictor of sustained virological response after treatment with peginterferon and ribavirin in 432 chronically HCV infected patients, divided by age

\begin{tabular}{cccc}
\hline & Age $\leq \mathbf{4 5}$ years & Age $>\mathbf{4 5}$ years \\
\hline Genotype & $\mathbf{1}$ & Odds ratio $(\mathbf{9 5 \%} \mathrm{Cl}) \boldsymbol{*}$ & Odds ratio $(\mathbf{9 5 \%} \mathrm{Cl}) *$ \\
\hline & $\mathbf{2} / \mathbf{3}$ & 1 & 1 \\
\hline
\end{tabular}

*adjusted for gender, nationality, route of infection, HCV-RNA, ALT, treating department (gastroenterology/hepatology vs. infectious diseases), treatment completion as scheduled, ended before scheduled or dose reduction
$52 \%$ and $43 \%$ in genotypes 1, 2 and 3, respectively, although the patients included in this study were mainly men [12]. However, the present study demonstrated that the effectiveness of treatment, with SVR rates of 44$72 \%$, is comparable to the SVR rates reported in controlled, clinical trials of genotype $1-3$ patients [1,2]. The unique perspective of the present study is the nationwide, population based cohort design and a relatively large number of genotype 1, 2 and 3 infected patients included with an almost even distribution of males and females. As only very few patients in Denmark are treated at medical departments not participating in the DANHEP study, our study includes the vast majority of patients treated for $\mathrm{HCV}$ in Denmark during the study period.

In accordance with observations obtained in controlled, clinical trials we found both genotype and younger age to be predictors of SVR in patients treated with peginterferon and ribavirin $[1,5,6,25]$, but to our knowledge the present study is the only one, based on a nationwide cohort of unselected patients evenly distributed between males and females, treated in a routine clinical setting, thus representing an important confirmation of the effectiveness of treatment with pegylated interferon and ribavirin observed in controlled, clinical trials. In the present study, infection with genotype $2 / 3$ was a strong predictor of SVR, also in patients $\leq 45$ years, though statistical significance was not shown in this group.

In a study by Elefsiniotis et al. [10], genotype was not found as a predictor of SVR in patients younger than 35 years, and age was not a significant predictor of SVR in the overall cohort. However, in their analysis, age was used as a continuous variable. We have not been able to determine why certain cut off points for age have been chosen in other studies evaluating age as a predictive factor of SVR. In the present study, we evaluated whether or not age was best modeled as a continuous variable, or as a design variable dividing age in two groups. We found that the age of 45 was a relevant cut off point.

Even though Antonucci et al. [25] only included half as many patients with genotype 1 and a third as many with genotype $2 / 3$, as we did, in accordance with our results, they found that age of $<40$ years was a significant predictor of SVR in genotype 1 infected patients treated outside clinical trials. Similarly to Antonucci et al, we did not find younger age to be a statistically significant predictor of SVR in genotype $2 / 3$ infected patients. In our study however, there was a trend towards younger age also being a predictor of SVR in genotype 2/3 (OR: 0.58, 95\% CI: 0.33-1.00). Dalgard et al. [8] and Lagging et al. [9], included 428 and 382 highly selected genotype $2 / 3$ patients, respectively, and 
found that younger age predicted a higher chance of SVR. Older age at the time of infection is known to be associated with development of liver fibrosis [26-28]. Patients are carefully selected before initiation of antiviral treatment, because the overall treatment outcome is "poor", and treatment is lengthy, with many potentially severe side effects. International guidelines on whom to treat suggest that there should be evidence of liver fibrosis before treatment initiation in genotype 1 patients $[29,30]$. Due to the better treatment outcome and shorter treatment duration, patients infected with genotype 2 or 3 can start treatment without prior liver biopsy.

A former study, based on data from DANHEP [19], showed that patients infected with genotype $2 / 3$, had an approximately 2.5 times higher chance of starting antiviral treatment, while older age at referral was a negative predictor of treatment initiation. The results in the present study, with relatively high SVR rates in genotype 1 patients age 45 or younger, could have implications for future treatment strategy in this group of patients. Whether younger patients undergoing the new upcoming treatment regimens that add a specific HCV protease inhibitor to the standard of care treatment, can benefit from even shorter treatment periods remains to be seen. Clearly, further studies are required to establish the specific indications for treatment initiation in younger patients. Being infected with $\mathrm{HCV}$ has been shown to decrease quality of life, regardless of disease progression, and SVR after treatment improves quality of life [31]. This is another aspect that should be considered when deciding whether or not to treat patients for chronic hepatitis $\mathrm{C}$.

Recently, a genetic variation near the IL28B gene on chromosome 19 was found to be significantly associated with SVR in HCV infected genotype 1 patients, treated with peginterferon and ribavirin [32-34]. Ge et al. [32] found this advantageous genetic variation in $35 \%$ of the cohort examined. Patients with this variation had a 2-3 fold higher rate of SVR than other patients. Around 25$40 \%$ of the patients without the advantageous genetic variation gained SVR, and the genetic variation was only associated with an SVR in patients who did not become HCV RNA negative at week 4 in patients with genotypes 2 and 3 [35]. Therefore it is still important to identify and use other predictors of SVR when deciding whether to start treatment for $\mathrm{HCV}$ infection. Genetics do not change with age, therefore the main findings of the present study are still very important. It is possible that patients with genotype $1 \mathrm{HCV}$ infection without the advantageous IL28B genetic variation, identified in the studies mentioned above, could benefit from treatment before the age of 45 years.
The association between being of non-European origin and the high SVR rate could not be explained from our data. Thus, further research is needed to elucidate whether this difference could potentially be related to IL28B polymorphism differences, as the group of nonEuropeans was diverse ethnically and data on IL28Bpolymorphisms do not exist for all ethnicities involved in this study.

There are some limitations to the present study. The study is a retrospective observational study, and we are lacking information on some potentially important confounders such as weight, prior depression, and prior raised alcohol intake. We did not have any information on viral kinetics during treatment, and therefore we could not include this factor in the analyses. Furthermore, we did not have any knowledge of which patients were treated in clinical trials. It could have been interesting to determine if being treated in a clinical trial was a predictor of SVR.

\section{Conclusions}

We conclude that in a routine clinical practice the treatment effectiveness of patients with chronic $\mathrm{HCV}$ with peginterferon and ribavirin is equivalent to the effectiveness observed in clinical trials. Furthermore, genotype 2 and 3, age $\leq 45$ years at treatment initiation and completion of a non-modified treatment regimen is strongly associated with a sustained treatment response. Thus, our study on a nationwide Danish cohort shed new light on combination therapy of chronic HCV.

\section{Potential conflict of interest}

Peer Brehm Christensen is member of the Advisory Board for Roche A/S and has received research grants from Roche A/S and Sheering Plough.

Nanna Hansen; No conflict, Niels Obel; No conflict, Mette Kjær; No conflict, Alex Lund Laursen; No conflict, Henrik Bygum Krarup; No conflict, Axel Møller; No conflict, Poul Schlichting; No conflict, Jens Bukh; No conflict, Nina Weis; No conflict.

No authors listed in appendix 1 have any conflict of interest

\section{Acknowledgements and Funding}

Additional members of the DANHEP group:

Hans Kromann-Andersen, Department of Gastroenterology, Koege University Hospital, Suzanne Lunding, Department of Internal Medicine, Helsingoer Hospital, Karin Groenbaek, Department of Gastroenterology, Copenhagen University Hospital, Hvidovre, Peter Noerregaard, Department of Internal Medicine, Frederiksberg Hospital, Kim Krogsgaard, Copenhagen University Hospital, Hvidovre, Jens Lindberg, Department of Internal Medicine, Herning Hospital, Henrik Nielsen, Department of Infectious Diseases, Aalborg University Hospital, Jens Ole Nielsen, Department of Infectious Diseases, Copenhagen University Hospital, Hvidovre, Ove B. Schaffalitzky de Muckadell, Department of Gastroenterology, Odense University Hospital. 
We are grateful to the staff of the participating clinical departments for their continuous support of recording data in DANHEP. We also thank statistician Steen Ladelund, Clinical Research Centre, Copenhagen University Hospital, Hvidovre, Denmark, for statistical advice.

This study was supported by The Lundbeck Foundation (grant support to Jens Bukh) and the A.P. Møller Foundation for the Advancement of Medical Science (grant support to Nina Weis).

\section{Author details}

'Department of Infectious Diseases, Copenhagen University Hospital, Hvidovre, 2650 Hvidovre, Denmark. ${ }^{2}$ Department of Infectious Diseases, Copenhagen University Hospital, Rigshospitalet, 2100 Copenhagen $\varnothing$, Denmark. ${ }^{3}$ Department of Infectious Diseases, Odense University Hospital, 5000 Odense, Denmark. ${ }^{4}$ Department of Hepatology, Copenhagen University Hospital, Rigshospitalet, 2100 Copenhagen $\varnothing$, Denmark. ${ }^{5}$ Department of Infectious Diseases, Aarhus University Hospital, Skejby, 8000 Aarhus, Denmark. ${ }^{6}$ Department of Gastroenterology and Biochemistry, Unit for Molecular Diagnostics, Aalborg University Hospital, 9100 Aalborg, Denmark. ${ }^{7}$ Department of Internal Medicine, Kolding Hospital, 6000 Kolding, Denmark. ${ }^{8}$ Department of Gastroenterology, Herlev University Hospital, 2730 Herlev, Denmark. ${ }^{9}$ Copenhagen Hepatitis C Program (CO-HEP), Department of Infectious Diseases and Clinical Research Centre, Copenhagen University Hospital, Hvidovre, 2650 Hvidovre, Denmark and Department of International Health, Immunology and Microbiology, Faculty of Health Sciences, University of Copenhagen, 2100 Copenhagen $\varnothing$, Denmark. ${ }^{10}$ Faculty of Health Sciences, University of Copenhagen, Denmark, 2100 Copenhagen $\varnothing$, Denmark.

\section{Authors' contributions}

$\mathrm{NH}, \mathrm{NO}, \mathrm{JB}, \mathrm{NW}$ have made substantial contributions to conception and design, analysis and interpretation of data and drafting the manuscript; $\mathrm{NH}$, NO, PBC, MK, ALL, HBK, AM, PS, JB, NW have made substantial contributions to acquisition of data and all authors contributed with a critical revision of the manuscript and read and approved the final manuscript.

Received: 11 December 2010 Accepted: 21 June 2011 Published: 21 June 2011

\section{References}

1. Manns MP, McHutchison JG, Gordon SC, Rustgi VK, Shiffman M Reindollar R, Goodman ZD, Koury K, Ling M, Albrecht JK: Peginterferon $a l f a-2 b$ plus ribavirin compared with interferon alfa- $2 b$ plus ribavirin for initial treatment of chronic hepatitis C: a randomised trial. Lancet 2001, 358:958-65.

2. Fried MW, Shiffman ML, Reddy KR, Smith C, Marinos G, Goncales FL, Häussinger D, Diago M, Carosi G, Dhumeaux D, Craxi A, Lin A, Hoffman J, Yu J: Peginterferon alfa-2a plus ribavirin for chronic hepatitis $C$ virus infection. N Engl J Med 2002, 347:975-82.

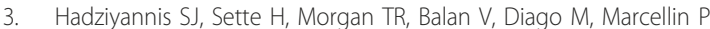
Ramadori G, Bodenheimer H Jr, Bernstein D, Rizzetto M, Zeuzem S, Pockros PJ, Lin A, Ackrill AM, PEGASY International Study Group: Peginterferon-alpha2a and ribavirin combination therapy in chronic hepatitis $\mathrm{C}$ : a randomized study of treatment duration and ribavirin dose. Ann Intern Med 2004, 140:346-55.

4. Hofmann WP, Zeuzem S: A new standard of care for the treatment of chronic HCV infection. Nat Rev Gastroenterol Hepatol 2011, Epub April 5.

5. Kau A, Vermehren J, Sarrazin C: Treatment predictors of a sustained virologic response in hepatitis B and C. J Hepatol 2008, 49:634-51.

6. Foster GR, Fried MW, Hadziyannis SJ, Messinger D, Freivogel K, Weiland O: Prediction of sustained virological response in chronic hepatitis $C$ patients treated with peginterferon alfa-2a (40KD) and ribavirin. Scand J Gastroenterol 2007, 42:247-55.

7. Zeuzem S, Buti M, Ferenci P, Sperl J, Horsmans Y, Cianciara J, Ibranyi E, Weiland O, Noviello S, Brass C, Albrecht J: Efficacy of 24 weeks treatment with peginterferon alfa- $2 \mathrm{~b}$ plus ribavirin in patients with chronic hepatitis $C$ infected with genotype 1 and low pretreatment viremia. J Hepatol 2006, 44:97-103.

8. Dalgard O, Bjoro K, Ring-Larsen H, Bjornsson E, Holberg-Petersen M, Skovlund E, Reichard O, Myrvang B, Sundelöf B, Ritland S, Hellum K, Frydén A, Florholmen J, Verbaan H, North-C group: Pegylated interferon alfa and ribavirin for 14 versus 24 weeks in patients with hepatitis C virus genotype 2 or 3 and rapid virological response. Hepatology 2008, 47:35-42.

9. Lagging M, Langeland N, Pedersen C, Farkkila M, Buhl MR, Morch K, Dhillon AP, Alsiö A, Hellstrand K, Westin J, Norkrans G, NORDynamlC Study Group: Randomized comparison of 12 or 24 weeks of peginterferon alpha-2a and ribavirin in chronic hepatitis $C$ virus genotype $2 / 3$ infection. Hepatology 2008, 47:1837-45.

10. Elefsiniotis IS, Pavlidis C, Ketikoglou I, Koutsounas S, Scarmeas N, Pantazis KD, Moulakakis A, Tsianos EV: Patient's age modifies the impact of the proposed predictors of sustained virological response in chronic hepatitis C patients treated with PEG-interferon plus ribavirin. Eur J Intern Med 2008, 19:266-70.

11. Missiha S, Heathcote J, Arenovich T, Khan K: Impact of asian race on response to combination therapy with peginterferon alfa- $2 \mathrm{a}$ and ribavirin in chronic hepatitis C. Am J Gastroenterol 2007, 102:2181-8.

12. Backus LI, Boothroyd DB, Phillips BR, Mole LA: Predictors of response of US veterans to treatment for the hepatitis C virus. Hepatology 2007, 46:37-47.

13. Shiffman ML, Suter F, Bacon BR, Nelson D, Harley H, Sola R, Shafran SD, Barange K, Lin A, Soman A, Zeuzem S: Peginterferon alfa-2a and ribavirin for 16 or 24 weeks in HCV genotype 2 or 3. N Engl J Med 2007, 357:124-34.

14. Shirakawa H, Matsumoto A, Joshita S, Komatsu M, Tanaka N, Umemura T, Ichijo T, Yoshizawa K, Kiyosawa K, Tanaka E: Pretreatment prediction of virological response to peginterferon plus ribavirin therapy in chronic hepatitis C patients using viral and host factors. Hepatology 2008, 48:1753-60.

15. Mangia A, Santoro R, Minerva N, Ricci GL, Carretta V, Persico M, Vinelli F, Scotto G, Bacca D, Annese M, Romano M, Zechini F, Sogari F, Spirito F, Andriulli A: Peginterferon alfa-2b and ribavirin for 12 vs. 24 weeks in HCV genotype 2 or 3. N Engl J Med 2005, 352:2609-17.

16. Lagging M, Langeland N, Pedersen C, Farkkila M, Buhl MR, Morch $K$, Dhillon AP, Alsiö A, Hellstrand K, Westin J, Christensen P, Leutscher P, Norkrans G: Weight-adjusted dosing of ribavirin and importance of hepatitis C virus RNA below $1000 \mathrm{IU} / \mathrm{mL}$ by day 7 in short-term peginterferon therapy for chronic genotype $2 / 3$ hepatitis $C$ virus infection. Hepatology 2008, 48:695.

17. Loustaud-Ratti V, Alain S, Rousseau A, Hubert IF, Sauvage FL, Marquet $P$, Denis F, Lunel F, Calès $P$, Lefebvre A, Fauchais AL, Liozon E, Vidal E: Ribavirin exposure after the first dose is predictive of sustained virological response in chronic hepatitis C. Hepatology 2008, 47:1453-61.

18. Danmarks statistik. 2008 [http://www.dst.dk], Ref Type: Internet Communication.

19. Hansen N, Obel N, Christensen PB, Krarup H, Laursen AL, Clausen MR, Lunding S, Møller A, Schlichting P, Kromann-Andersen H, Bukh J, Weis N: Predictors of antiviral treatment initiation in hepatitis $C$ virus-infected patients: a Danish cohort study. I Viral Hepat 2009, 16:659-65.

20. Krarup HB, Drewes AM, Madsen PH: A quantitative HCV-PCR test for routine diagnostics. Scand J Clin Lab Invest 1998, 58:415-22.

21. Krarup HB, Moller JM, Christensen PB, Fuglsang T, Ingerslev J, Arnfred T, Madsen PH: Haemophilic patients with hepatitis $\mathrm{C}$ have higher viral load compared to other well-defined patient groups. J Viral Hepat 2000, 7:435-9.

22. Corbet $\mathrm{S}$, Bukh J, Heinsen A, Fomsgaard A: Hepatitis $C$ virus subtyping by a core-envelope 1-based reverse transcriptase PCR assay with sequencing and its use in determining subtype distribution among Danish patients. J Clin Microbiol 2003, 41:1091-100.

23. Laperche S, Le Marrec N, Girault A, Bouchardeau F, Servant-Delmas A, Maniez-Montreuil M, Gallian P, Levayer T, Morel P, Simon N: Simultaneous detection of hepatitis $\mathrm{C}$ virus (HCV) core antigen and anti-HCV antibodies improves the early detection of HCV infection. J Clin Microbiol 2005, 43:3877-83.

24. Bedossa P, Poynard T: An algorithm for the grading of activity in chronic hepatitis C. The METAVIR Cooperative Study Group. Hepatology 1996, 24:289-93.

25. Antonucci G, Longo MA, Angeletti C, Vairo F, Oliva A, Comandini UV, Tocci G, Boumis E, Noto P, Solmone MC, Capobianchi MR, Girardi E: The effect of age on response to therapy with peginterferon alpha plus ribavirin in a cohort of patients with chronic HCV hepatitis including subjects older than 65 yr. Am J Gastroenterol 2007, 102:1383-91.

26. Marcellin $\mathrm{P}$, Asselah $\mathrm{T}$, Boyer $\mathrm{N}$ : Fibrosis and disease progression in hepatitis C. Hepatology 2002, 36(5 Suppl 1):S47-S56. 
27. Yano M, Kumada H, Kage M, Ikeda K, Shimamatsu K, Inoue $O$, Hashimoto $E$, Lefkowitch JH, Ludwig J, Okuda K: The long-term pathological evolution of chronic hepatitis C. Hepatology 1996, 23:1334-40.

28. Chen SL, Morgan TR: The natural history of hepatitis C virus (HCV) infection. Int J Med Sci 2006, 3:47-52.

29. Strader DB, Wright T, Thomas DL, Seeff LB: Diagnosis, management, and treatment of hepatitis C. Hepatology 2004, 39:1147-71.

30. Wejstal R, Alaeus A, Fischler B, Reichard O, Uhnoo I, Weiland O: Chronic hepatitis C: updated Swedish consensus. Scand J Infect Dis 2003, 35:445-51.

31. Younossi Z, Kallman J, Kincaid J: The effects of HCV infection and management on health-related quality of life. Hepatology 2007, 45:806-16.

32. Ge D, Fellay J, Thompson AJ, Simon JS, Shianna KV, Urban TJ, Heinzen EL, Qui P, Bertelsen AH, Muir AJ, Sulkowski M, McHutchison JG, Goldstein DB: Genetic variation in IL28B predicts hepatitis C treatment-induced viral clearance. Nature 2009, 461:399-401.

33. Suppiah V, Moldovan M, Ahlenstiel G, Berg T, Weltman M, Abate ML, Bassendine M, Spengler U, Dore GJ, Powell E, Riordan S, Sheridan D, Smedile A, Fragomeli V, Mûller T, Bahlo M, Stewart GJ, Booth DR, George J: IL28B is associated with response to chronic hepatitis $C$ interferon-alpha and ribavirin therapy. Nat Genet 2009, 41:1100-4.

34. Tanaka Y, Nishida N, Sugiyama M, Kurosaki M, Matsuura K, Sakamoto N, Nakagawa M, Korenaga M, Hino K, Hige S, Ito Y, Mita E, Tanaka E, Mochida S, Murawaki Y, Honda M, Sakai A, Hiasa Y, Nishiguchi S, Koike A, Sakaida I, Imamura M, Ito K, Yano K, Masaki N, Sugauchi F, Izumi N, Tokunaga K, Mizokami M: Genome-wide association of IL28B with response to pegylated interferon-alpha and ribavirin therapy for chronic hepatitis C. Nat Genet 2009, 41:1105-9.

35. Mangia A, Thompson AJ, Santoro R, Piazolla V, Tillmann HL, Patel K, Shianna KV, Mottola L, Petruzzellis D, Bacca D, Carretta V, Minerva N, Goldstein DB, McHutchison JG: An IL28B polymorphism determines treatment response of hepatitis $C$ virus genotype 2 or 3 patients who do not achieve a rapid virological response. Gastroenterology 2010, 130:821-27.

\section{Pre-publication history}

The pre-publication history for this paper can be accessed here: http://www.biomedcentral.com/1471-2334/11/177/prepub

doi:10.1186/1471-2334-11-177

Cite this article as: Hansen et al:: Effectiveness of treatment with pegylated interferon and ribavirin in an unselected population of patients with chronic hepatitis C: A Danish nationwide cohort study. BMC Infectious Diseases 2011 11:177.

\section{Submit your next manuscript to BioMed Central and take full advantage of:}

- Convenient online submission

- Thorough peer review

- No space constraints or color figure charges

- Immediate publication on acceptance

- Inclusion in PubMed, CAS, Scopus and Google Scholar

- Research which is freely available for redistribution

Submit your manuscript at www.biomedcentral.com/submit
Biomed Central 